\title{
Life cycle assessment of soybean-based biodiesel in Argentina for export
}

\author{
Luis Panichelli • Arnaud Dauriat • Edgard Gnansounou
}

Received: 23 April 2008 / Accepted: 13 November 2008

(C) Springer-Verlag 2008

\begin{abstract}
Background, aim and scope Regional specificities are a key factor when analyzing the environmental impact of a biofuel pathway through a life cycle assessment (LCA). Due to different energy mixes, transport distances, agricultural practices and land use changes, results can significantly vary from one country to another. The Republic of Argentina is the first exporter of soybean oil and meal and the third largest soybean producer in the world, and therefore, soybean-based biodiesel production is expected to significantly increase in the near future, mostly for exportation. Moreover, Argentinean biodiesel producers will need to evaluate the environmental performances of their product in order to comply with sustainability criteria being developed. However, because of regional specificities, the environmental performances of this biofuel pathway can be expected to be different from those obtained for other countries and feedstocks previously studied. This work aims at analyzing the environmental impact of soybean-based biodiesel production in Argentina for export. The relevant impact categories account for the primary non-renewable energy consumption (CED), the global warming potential (GWP), the eutrophication potential
\end{abstract}

Responsible editor: Robert Anex

L. Panichelli $\cdot$ E. Gnansounou $(\bowtie)$

École Polytechnique Fédérale de Lausanne,

LASEN-ICARE-ENAC,

Station 18, EPFL,

1015 Lausanne, Switzerland

e-mail: edgard.gnansounou@epfl.ch

\section{A. Dauriat}

ENERS Energy Concept,

Av. Saint-Paul,

111004 Lausanne, Switzerland
(EP), the acidification potential (AP), the terrestrial ecotoxicity (TE), the aquatic ecotoxicity (AE), the human toxicity (HT) and land use competition (LU). The paper tackles the feedstock and country specificities in biodiesel production by comparing the results of soybean-based biodiesel in Argentina with other reference cases. Emphasis is put on explaining the factors that contribute most to the final results and the regional specificities that lead to different results for each biodiesel pathway.

Materials and methods The Argentinean (AR) biodiesel pathway was modelled through an LCA and was compared with reference cases available in the ecoinvent ${ }^{\circledR} 2.01$ database, namely, soybean-based biodiesel production in Brazil (BR) and the United States (US), rapeseed-based biodiesel production in the European Union (EU) and Switzerland $(\mathrm{CH})$ and palm-oil-based biodiesel production in Malaysia (MY). In all cases, the systems were modelled from feedstock production to biodiesel use as B100 in a $28 \mathrm{t}$ truck in $\mathrm{CH}$. Furthermore, biodiesel pathways were compared with fossil low-sulphur diesel produced and used in $\mathrm{CH}$. The LCA was performed according to the ISO standards. The life cycle inventory and the life cycle impact assessment (LCIA) were performed in Excel spreadsheets using the ecoinvent ${ }^{\circledR} 2.01$ database. The cumulative energy demand (CED) and the GWP were estimated through the CED for fossil and nuclear energy and the IPCC 2001 (climate change) LCIA methods, respectively. Other impact categories were assessed according to CML 2001, as implemented in ecoinvent. As the product is a fuel for transportation (service), the system was defined for one vehicle kilometre (functional unit) and was divided into seven unit processes, namely, agricultural phase, soybean oil extraction and refining, transesterification, transport to port, transport to the destination country border, distribution and utilisation. 
Results The Argentinean pathway results in the highest GWP, CED, AE and HT compared with the reference biofuel pathways. Compared with the fossil reference, all impact categories are higher for the AR case, except for the CED. The most significant factor that contributes to the environmental impact in the Argentinean case varies depending on the evaluated category. Land provision through deforestation for soybean cultivation is the most impacting factor of the AR biodiesel pathway for the GWP, the CED and the HT categories. Whilst nitrogen oxide emissions during the fuel use are the main cause of acidification, nitrate leaching during soybean cultivation is the main factor of eutrophication. LU is almost totally affected by arable land occupation for soybean cultivation. Cypermethrin used as pesticide in feedstock production accounts for almost the total impact on TE and AE.

Discussion The sensitivity analysis shows that an increase of $10 \%$ in the soybean yield, whilst keeping the same inputs, will reduce the total impact of the system. Avoiding deforestation is the main challenge to improve the environmental performances of soybean-based biodiesel production in AR. If the soybean expansion can be done on marginal and set-aside agricultural land, the negative impact of the system will be significantly reduced. Further implementation of crops' successions, soybean inoculation, reduced tillage and less toxic pesticides will also improve the environmental performances. Using ethanol as alcohol in the transesterification process could significantly improve the energy balance of the Argentinean pathway.

Conclusions The main explaining factors depend on regional specificities of the system that lead to different results from those obtained in the reference cases. Significantly different results can be obtained depending on the level of detail of the input data, the use of punctual or average data and the assumptions made to build up the LCA inventory. Further improvement of the AR biodiesel pathways should be done in order to comply with international sustainability criteria on biofuel production.

Recommendations and perspectives Due to the influence of land use changes in the final results, more efforts should be made to account for land use changes others than deforestation. More data are needed to determine the part of deforestation attributable to soybean cultivation. More efforts should be done to improve modelling of interaction between variables and previous crops in the agricultural phase, future transesterification technologies and market prices evolution. In order to assess more accurately the environmental impact of soybean-based biodiesel production in Argentina, further considerations should be made to account for indirect land use changes, domestic biodiesel consumption and exportation to other regions, production scale and regional georeferenced differentiation of production systems.
Keywords Agriculture $\cdot$ Argentina $\cdot$ Biodiesel $\cdot$ Explaining factors $\cdot$ Export $\cdot$ Land use changes $\cdot$ LCA $\cdot$ Modelling .

Soybean-based biodiesel production

\section{Background, aim and scope}

Life cycle assessment (LCA) of biofuel production requires a country-specific approach due to the significant importance of local conditions in estimating the energy consumption and the greenhouse gas emissions of the system. Some efforts have been put worldwide to determine countryspecific and raw-material-specific biofuels environmental impact (RFA 2008; Reijnders and Huijbregts 2008; Russi 2008; Zah et al. 2007; CONCAWE-EUCAR-JRC 2007; Smith et al. 2007; Farrell et al. 2006; Gnansounou and Dauriat 2005; VIEWLS 2005; Bernesson et al. 2004; Elsayed et al. 2003; ADEME 2002; GM-LBST 2002; Sheehan et al. 1998).

However, due to different system boundaries, functional unit, allocation methods and other assumptions in LCA approaches, results are difficult to compare. The LCA of bioenergy products within the ecoinvent ${ }^{\circledR} 2.01$ database is a first attempt to develop environmental impact factors for country-specific and feedstock-specific biofuel pathways under a consistent methodology (Jungbluth et al. 2007). A structured and transparent methodology was applied to develop environmental impact factors for soybean-based biodiesel from Brazil (BR) and the United States (US), rapeseed-based biodiesel from the European Union (EU) and Switzerland $(\mathrm{CH})$, palm-oil-based biodiesel from Malaysia (MY) and fossil diesel from Switzerland (CH). However, soybean-based biodiesel from Argentina (AR) was not included.

In the framework of biofuel research at LASEN, a biofuel platform was developed to test the influence of modelling choices in LCA results. The model is based on the ecoinvent ${ }^{\circledR}$ database and represents biofuel pathways from feedstock production to fuel utilisation. A first case study was developed using wheat-based bioethanol production and utilisation in $\mathrm{CH}$ (Gnansounou et al. 2008). The platform was then used to generate a detailed life cycle inventory (LCI) and LCA of soybean-based biodiesel from AR.

The Republic of Argentina is the first exporter of soybean oil and meal and the third largest soybean producer in the world, and therefore, biodiesel production from this source is expected to significantly increase in the next years, mostly for exportation. Nonetheless, a consistent life cycle approach was not yet applied to evaluate the environmental performance of this country-specific biofuel pathway. 
Argentina is the third largest vegetable oil producer in the world (5.40 Mt in 2005) and the first soybean oil exporter in the world (4.83 Mt in 2005; SAGPyA-IICA 2005). Soybean represents $53 \%$ of the country's cultivated area with grains, and $88 \%$ of this surface is concentrated in the central region of the country (Buenos Aires, Córdoba and Santa $\mathrm{Fe}$ ) representing $83 \%$ of the national soybean production (Fig. 1).

Soybean oil is mainly exported to China (36\%), India (21\%) and Bangladesh (5\%; Franco 2005a), and together with sunflower oil, it represents $99 \%$ of the national average milling capacity. In 2004, 47 vegetable oil mills were operating and concentrated mainly in Santa Fe (72\%), Buenos Aires (15\%) and Cordoba (11\%; Ciani and Esposito 2005). At present, there are eight biodiesel production plants installed in Argentina, with a production capacity of $600 \mathrm{kt} \mathrm{year}^{-1}$ of biodiesel. Of the total production, $318 \mathrm{kt}$ of biodiesel was exported in 2007 , from which $76 \%$ were destined to the US and $23 \%$ to the EU. The production capacity is expected to double by the end of 2008 (SAGPyA 2008).

An increased interest in biofuel production in Argentina has been observed in recent years. Argentina has been ranked as the third country in the world with the highest potential for biodiesel production (Johnston and Holloway 2007). This statement relies on the availability of soybean oil for export, the low production costs and the good socioeconomic conditions. The biodiesel production potential is of $5.26 \mathrm{Bl}$, accounting for $51 \%$ of the country's diesel demand. The Argentinean government has established a 5\% mandatory blending of biofuels in conventional fuels for transportation by 2010 . The main feedstock is expected to be soybean due to the large availability of this product in the country. If so, $650 \mathrm{Ml}$ of soybean-based biodiesel (i.e. 3.5 Mt of soybeans and 1.2 Mha) will be required to comply with the national obligation (SAGPyA-IICA 2005). Moreover, due to the exporting structure of Argentinean commodities, biodiesel production is seen as an opportunity to expand the exports portfolio. Even though biodiesel production is still incipient, it is expected to grow rapidly due to the mandatory blending law, the increased international demand for biofuels, the availability of feedstock and the high agro-exporting efficiency of the vegetable oil sector. These factors determine competitive costs for biodiesel production.

On the other hand, current initiatives, especially in the US (Farrell and Sperling 2007a, b) and the EU (Bauen et al. 2007; Cramer et al. 2007), to account for sustainability aspects of biofuel production may constrain the exporting opportunities of Argentinean biodiesel. A key criterion is the greenhouses gas (GHG) emission balance of the biofuel. Therefore, the aim of this paper was to evaluate the position of Argentina as a producer of sustainable biodiesel in comparison with other worldwide suppliers.

This study aims at determining the environmental impact of vegetable oil methyl ester (VOME) production from

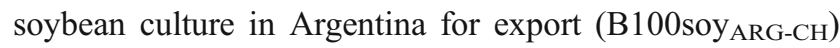
through a LCA. The biodiesel pathway is modelled up to the exportation port, as results can significantly change depending on the destination country. However, for purposes of comparison with the reference systems and in order to illustrate the impact of the transportation and the utilisation phase, the biodiesel pathway was also modelled for export to Switzerland.

Emphasis is put on the modelling of the Argentinean case and in understanding the main factors that influence the final results and that explain the main differences between producing countries.
Fig. 1 Soybean production area in Argentina. Adapted from SAGPyA (2006a)

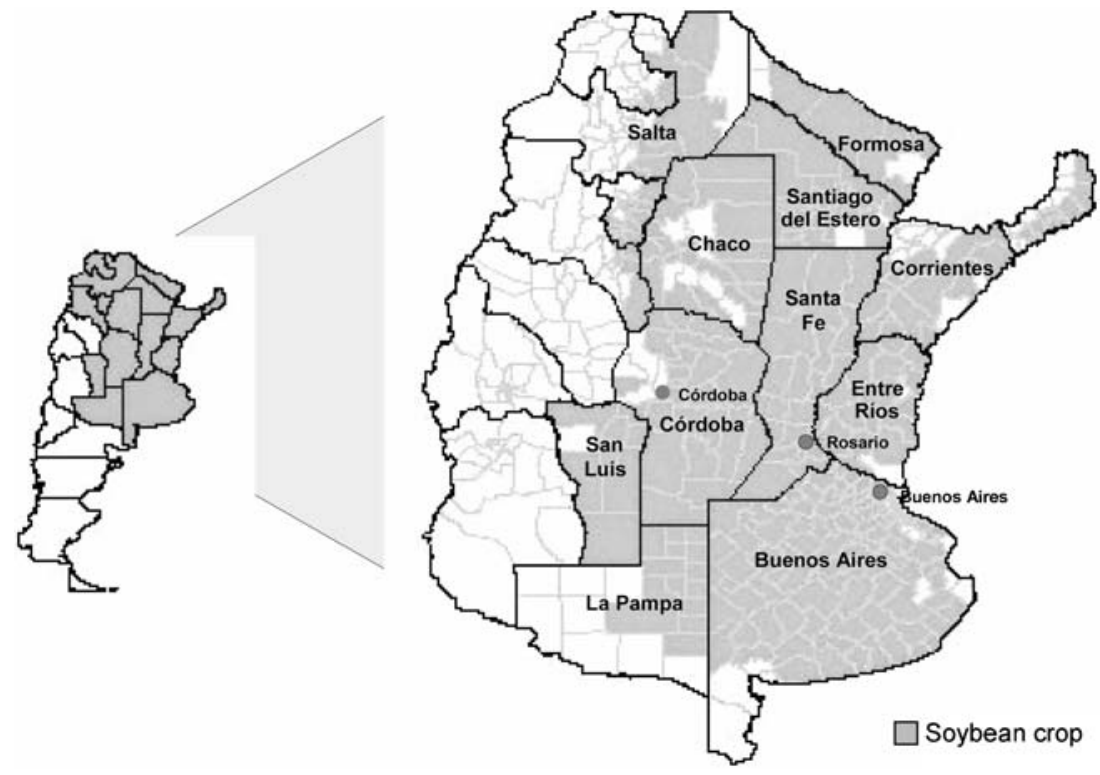




\section{Materials and methods}

The LCA was performed according to the ISO standards on LCA (ISO 2006a, b) and to the main steps described in ISO norm 14041. The LCI and the life cycle impact assessment (LCIA) were performed in the biofuel platform model developed at LASEN integrating Microsoft Excel ${ }^{\circledR}$ spreadsheets and using the ecoinvent ${ }^{\circledR} 2.01$ database (Frischknecht et al. 2004; Frischknecht 2005).

\subsection{Key parameters, assumptions and data quality}

The system was defined from a well-to-wheels approach. The functional unit is ' $1 \mathrm{~km}$ driven with diesel by a $28 \mathrm{t}$ truck'. The function of the system is to deliver 'fuel for transportation'. The LCIA methods are non-renewable cumulative energy demand (CED) for the CED, IPCC 2001 GWP 100a (climate change) for GWP, CML 2001 generic for eutrophication potential (EP), CML 2001 generic for acidification potential (AP), CML 2001 TAETP 100a for terrestrial ecotoxicity (TE), CML 2001 FAETP 100a for aquatic ecotoxicity (AE), CML 2001 HTP 100a for human toxicity (HT) and CML 2001 for land use competition (LU), available in the ecoinvent ${ }^{\circledR} 2.01$ database. The system description is valid for soybean-based biodiesel in Argentina (country-specific approach) and for a time framework 2006-2010, as technologies, prices and production methods are assumed to change in the medium term.

The reference biodiesel pathways are those available from the ecoinvent ${ }^{\circledR} 2.01$ database, and the reference systems are described as follows:

- B100soy BR-CH soybean-based VOME produced in BR and used in $\mathrm{CH}$;

- B100soy us-CH soybean-based VOME produced in the US and used in $\mathrm{CH}$;

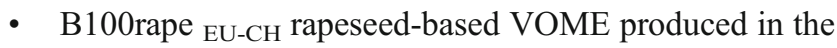
$\mathrm{EU}$ and used in $\mathrm{CH}$;

- B100rape $\mathrm{CH}-\mathrm{CH}$ rapeseed-based VOME produced in $\mathrm{CH}$ and used in $\mathrm{CH}$;

- B100palm MY-CH palm-based VOME produced in MY and used in $\mathrm{CH}$;

- D100fossil $\mathrm{CH}-\mathrm{CH}$ fossil diesel produced and used in $\mathrm{CH}$.

Rapeseed production for biodiesel in Switzerland is calculated as an average of different agricultural production methods, namely, organic (1\%), extensive (28\%) and integrated $(71 \%)$ production. Rapeseed production in the European Union corresponds to conventional rapeseed production in Germany.

Economic allocation was based on market values. Soybean oil and soybean meal allocation was based on international market prices, as these products are exported.
However, as glycerine is destined to national consumption, national market price was used. B100 soy $_{\mathrm{ARG}-\mathrm{CH}}$ market price was assumed to be that of US VOME.

Although the ISO norm recommends subdividing the system or performing system expansion as methods instead of allocation, economic allocation has been chosen essentially because soybean meal is a commodity with a defined market value. Moreover, the decision was taken in coherence with the ecoinvent database for bioenergy products (Jungbluth et al. 2007) where allocation of environmental impacts between co-products is based on the respective prices of co-products. Nonetheless, sensitivity analysis was performed for allocation based on energy content, mass and carbon content to evaluate the variability of results with regard to this key methodological parameter.

Only carbon dioxide $\left(\mathrm{CO}_{2}\right)$, methane $\left(\mathrm{CH}_{4}\right)$ and nitrous oxide $\left(\mathrm{N}_{2} \mathrm{O}\right)$ emissions are considered for GWP assessment. Emissions from land use change other than direct deforestation are excluded due to lack of data.

The quality of the used data is consistent with the objectives of the study. However, since the production of biodiesel in Argentina so far remains a marginal activity, transesterification data are based on average international technology, consistent with the information found in ecoinvent ${ }^{\circledR}$. Agricultural data are specific to the Argentinean context. Vegetable oil production and transesterification, however, were adapted to the Argentinean context with data from the US and average European reference cases (Jungbluth et al. 2007).

Soybean yield per hectare is based on the average yield from the last five available harvesting periods (2000/20012004/2005). Transport distances are based on average distances and do not correspond to a specific case. No data was available for the soybean intermediate storage and drying phase. Consequently, this stage was not considered in the system boundaries, and it was assumed to take place only at the vegetable oil extraction plant.

The relevance of the data quality was studied through sensitivity analysis of key input values with a significant impact on the final results.

\subsection{System description and inventory data}

The Argentinean soybean-based biodiesel pathway was divided into seven unit processes, namely, agricultural phase (soybean production), soybean oil extraction and refining (oil production), transesterification of soybean oil (VOME production), VOME transport to port in AR, VOME transport from port to the Swiss border, VOME distribution in $\mathrm{CH}$ and VOME use in $\mathrm{CH}$. The listed inputs and outputs are the ones necessary to evaluate the selected impact categories. 
The AR agricultural phase is specifically detailed and based on national values. Due to lack of data in oil extraction and transesterification, these processes were constructed on the US case, but adapted to the AR context. The country-specific data are detailed in the following sections.

\subsection{Soybean production}

The characteristics of the production system are estimated as averages based on the four soybean production systems in Argentina: first- and second-class soybean in reduced tillage (FCRT and SCRT) and first- and second-class soybean in conventional tillage (FCCT and SCCT).

The distribution of the total production between the systems is $49.3 \%, 30.6 \%, 14.7 \%$ and $5.4 \%$, respectively (SAGPyA 2006a). The average soybean yield is $2,591 \mathrm{~kg} \mathrm{ha}^{-1}$ (SAGPyA 2006a) and is calculated as the weighted average yield of the four production systems with regard to their respective shares of national production.

First class soybean is grown between October/November (sowing) and April/May (harvesting), corresponding to the optimal growing period for soybean in Argentina. The soybean cycle lasts for 6 months, and the land is then left and set aside during the winter (crop succession of set-aside land-soybean). Second-class soybean is grown between December (sowing) and April/May (harvesting), after wheat (crop succession of wheat-soybean). Therefore, soybeans of shorter growing cycle are used. Wheat is grown between June/July and December (harvesting) and soybean is sowed at the same time wheat is harvested. This allows having two crops per year on that land. However, as first class soybean is grown in the optimal period, higher yields are obtained compared with second-class soybean.

Both first- and second-class soybeans are grown in monoculture as well as in rotation with corn or sunflower. However, no data is available of the proportion of each soybean type done in monoculture and in rotation.

Phosphate fertilisers are imported from US, Russia, Lithuania, Morocco and Tunisia. NPK formulations are imported from Brazil and Uruguay (SAGPyA 2006b). Pesticides and fertilisers are available at regional storage (port of Rosario) and are transported over $300 \mathrm{~km}$ in $28 \mathrm{t}$ trucks to the local area and $30 \mathrm{~km}$ by tractor or trailer to the field (SAGPyA 2006b). Soybeans are transported over $30 \mathrm{~km}$ by tractor to the regional storage. Seed input varies depending on the production method, being 75, 70, 80 and $70 \mathrm{~kg} \mathrm{ha}^{-1}$ for FCRT, SCRT, FCCT and SCCT, respectively.

Land occupation is estimated as 1 year for first-class soybean (only soybean) and 0.5 year for second-class soybean (soybean-wheat production). Soybean area has increased from 10.7 Mha in 2000 to 15.3 Mha in 2005 (4.7 Mha; SAGPyA, 2006a), displacing other crops (32\%), mainly wheat, corn, sunflower and sorghum, pasture land $(27 \%)$, savannas $(19 \%)$ and forest $(22 \%$; Benbrook 2005 ; Gasparri et al. 2008; Montenegro et al. 2005; Paruelo et al. 2005). The land use is assumed arable land and transformation from arable land, shrub land, pasture and forest. Deforestation for soybean cultivation occurs in Salta, Chaco, Tucumán and Santiago del Estero (Grau et al. 2005; Gasparri and Manghi 2004) at an average rate of 258,406 ha year $^{-1}$ for the period 2000-2005. GHG emissions from deforestation are estimated as the emission from land provision and the emission from carbon stock change in soil, as implemented in ecoinvent ${ }^{\circledR}$, and totally allocated to the use as agricultural land. Soybean is assumed to be cultivated in deforested areas during 2 years. Land provision is estimated based on the deforested area between 2000 and $2005(1,550,435$ ha of the Chaco seasonally dry forest and 72,000 ha of the evergreen and semi-evergreen Yungas forest; Gasparri et al. 2008) and a rate attributed to soybean expansion $(64 \%$ of the total deforested area in the Northeast of Argentina; Pengue 2005). $\mathrm{CO}_{2}$ emissions from carbon stock change in soil ( $55 \mathrm{t} \mathrm{CO}_{2} \mathrm{ha}^{-1}$ year $^{-1}$ ) and biomass $\left(193 \mathrm{t} \mathrm{CO}_{2} \mathrm{ha}^{-1}\right.$ year $^{-1}$ ) were calculated by Gasparri et al. (2008) based on the IPCC Good Practice Guidance for LULUCF and the bookkeeping method (Houghton 2003). Carbon loss from soil after deforestation is estimated based on carbon stock change in soil from forest conversion to agricultural land $\left(15 \mathrm{t} \mathrm{C} \mathrm{ha}^{-1}\right.$ year $^{-1}$; Gasparri et al. 2008). Carbon stock change in soil represents only $7 \%$ of the total emission from land use conversion. Emissions from biomass (93\%) are accounted as provision of land by forest clearing.

Diesel consumption in agricultural processes was converted into inputs of agricultural field work processes according to ecoinvent ${ }^{\circledR}$ (Nemecek et al. 2007) in order to consider agricultural machinery production and use as well as exhaust emissions from the tractor. Diesel consumption in combined harvesting is $10.61 \mathrm{ha}^{-1}$. Fuel consumption in sowing, pesticide and fertiliser application is calculated based on primary data from Donato et al. (2005). Diesel consumption for agricultural activities other than harvesting is 25 and $521 \mathrm{ha}^{-1}$ for reduced and conventional tillage, respectively.

Pesticide and fertiliser use is the average of soybean cultivation in Argentina under the different production systems (Márgenes agropecuarios 2006). Nitrogen fertiliser is only applied to first-class soybean as monoammonium phosphate (MAP; $5 \mathrm{~kg} \mathrm{MAP} \mathrm{ha}{ }^{-1}$ ), whilst second class uses the residual fertilisation of the previously implanted crop (wheat). P fertiliser is applied as MAP and triple super phosphate (TSP) fertilisers in average doses of $5 \mathrm{~kg}$ MAP $\mathrm{ha}^{-1}$ and $10.5 \mathrm{~kg}$ TSP $\mathrm{ha}^{-1}$, respectively. Other fertilisers such as calcium sulphate and simple formulations of $\mathrm{P}$ and $\mathrm{S}$ were not included due to lack of data. No K fertiliser is 
applied in soybean production in Argentina (FAO 2004). Average pesticide applications (expressed in grams of active compound) are with deltamethrin $\left(67 \mathrm{~g} \mathrm{ha}^{-1}\right)$, difenoconazole (5 $\left.\mathrm{g} \mathrm{ha}^{-1}\right)$, cypermethrin $\left(45 \mathrm{~g} \mathrm{ha}^{-1}\right)$, chlorpyrifos ( $\left.421 \mathrm{~g} \mathrm{ha}^{-1}\right)$, endosulfan $\left(68 \mathrm{~g} \mathrm{ha}^{-1}\right)$, metribuzin $\left(14 \mathrm{~g} \mathrm{ha}^{-1}\right)$, acetochlor $\left(56 \mathrm{~g} \mathrm{ha}^{-1}\right)$, glyphosate $(2,340 \mathrm{~g}$ $\left.\mathrm{ha}^{-1}\right)$, 2,4-D $\left(240 \mathrm{~g} \mathrm{ha}^{-1}\right)$, metsulfuron methyl $\left(3 \mathrm{~g} \mathrm{ha}^{-1}\right)$ and imazetapyr $\left(3 \mathrm{~g} \mathrm{ha}^{-1}\right)$.

$\mathrm{N}_{2} \mathrm{O}$ emissions are calculated as a direct emission from the $\mathrm{N}$ input and an indirect emission from the $\mathrm{N}$ content in nitrate leaching, as implemented in ecoinvent ${ }^{\circledR} . \mathrm{N}$ input accounts for the $\mathrm{N}$ biological fixation (BNF) and for $\mathrm{N}$ fertiliser (Jungbluth et al. 2007). BNF is assumed to be $70 \mathrm{~kg} \mathrm{~N} \mathrm{ha}^{-1}$ as in the reference US and BR cases. Nitrogen oxides and ammonia emissions to air, nitrate and phosphorous emissions to groundwater and phosphorous emissions to surface water are estimated according to Nemecek et al. (2007), as implemented in Jungbluth et al. (2007).

Heavy metal emissions to soil are estimated as the difference between seed and fertilisers inputs and outputs, based on the BR case, as implemented in Jungbluth et al. (2007). Pesticide inputs are assumed as emissions to soil. Biogenic $\mathrm{CO}_{2}$ uptake $\left(1.37 \mathrm{~kg} \mathrm{~kg}^{-1}\right.$ soybean) and biomass energy (20.45 $\mathrm{MJ} \mathrm{kg}^{-1}$ soybean) are estimated from the carbon balance and the energy content in soybeans for the BR case, respectively. Soybean irrigation in Argentina is not a common practice, and the irrigated area is not significant.

\subsection{Soybean oil extraction and refining}

Solvent extraction technology (with methanol) is based on international standard technology, as described in Jungbluth et al. (2007) for VOME production. However, yields, allocation factors, natural gas and electricity consumption, electricity mix and transport distances are specific to the Argentinean context.

From $1 \mathrm{t}$ of soybean, $182 \mathrm{~kg}$ of soybean oil (19\%), $794 \mathrm{~kg}$ of soybean meal and $18 \mathrm{~kg}$ of residues are obtained. Soybean oil and soybean meal prices are US\$521 and US\$201 per ton, respectively (average January 2001-September 2006 at Rotterdam market; SAGPyA 2006c). Energy contents are assumed to be 37.2 and $17 \mathrm{MJ} \mathrm{kg}^{-1}$, respectively (Jungbluth et al. 2007). Soybeans are dried (from $16 \%$ to $13 \%$ humidity) in the vegetable oil mill using natural gas.

The electricity mix was modelled based on the electricity production in Argentina and accounts for the construction and operation of the power plants (SERA 2006). The Argentinean electricity mix is mainly dominated by fossil fuels $(50 \%$ natural gas and $38 \%$ oil). Electricity at grid was modelled based on the electricity mix accounting for transmission and distribution processes. The electricity and natural gas consumption corresponds to average values for vegetable oil mills in Santa Fe and Córdoba (IDIED 2004).
Utilities are transported over $150 \mathrm{~km}$ in $28 \mathrm{t}$ trucks. Vegetable oil mills are supplied with soybeans in a radius of $300 \mathrm{~km}$ being transported $80 \%$ by $28 \mathrm{t}$ trucks and $20 \%$ by train. Mill infrastructure is included in the same way as in all reference cases.

\subsection{Transesterification of soybean oil (methyl ester production)}

Soybean oil transesterification is based on international standard technology as implemented in Jungbluth et al. (2007) for VOME production, adapting allocation factors, natural gas and electricity consumption, electricity mix and transport distances to the Argentinean context. From $1 \mathrm{t}$ of soybean oil, $972.7 \mathrm{~kg}$ of soybean methyl ester and $106.1 \mathrm{~kg}$ of glycerine are obtained, considering methanol and potassium hydroxide addition.

Soybean methyl ester is produced for the international markets (US\$833 per ton-US market price) and glycerine is sold in the national market (US\$100 per ton-Argentina market price; Asal and Marcus 2005). Energy contents are assumed to be 37.2 and $18 \mathrm{MJ} \mathrm{kg}^{-1}$, respectively (Jungbluth et al. 2007).

Electricity and natural gas consumption are those of VOME production in the European Union. Chemicals are assumed to be supplied by chemical laboratories in Rosario, Córdoba and Buenos Aires from an average transport distance of $250 \mathrm{~km}$ in $28 \mathrm{t}$ trucks.

Vegetable oil mills are located near the ports of Rosario in the Paraná River. Consequently, $97 \%$ of the soybean oil, $97 \%$ of the soybean meal and $75 \%$ of the soybean are exported from this port (Franco 2005b). The transesterification plants are assumed to be located in the same place, and therefore, no transportation of soybean oil is assumed.

\subsection{Transport to exportation port, transport from port} to the $\mathrm{CH}$ border and distribution to service station in $\mathrm{CH}$

In Argentina, biodiesel is transported over $100 \mathrm{~km}$ in $28 \mathrm{t}$ trucks from the transesterification plant to the port of Rosario. It is then transported by transoceanic tanker from the ports of Rosario to the port of Rotterdam over an average distance of $12,091 \mathrm{~km}$. Finally, it is transported over $840 \mathrm{~km}$ in barge tanker to Basel, $100 \mathrm{~km}$ by train and $150 \mathrm{~km}$ in $28 \mathrm{t}$ trucks to the service station.

\subsection{Utilisation}

Biodiesel is assumed to completely replace fossil diesel in $28 \mathrm{t}$ trucks in $\mathrm{CH}$. Fuel economy is 0.27 and $0.25 \mathrm{~kg} \mathrm{~km}^{-1}$ for biodiesel and fossil diesel, respectively. The impact of the utilisation phase is assumed to be the same for all the biodiesel pathways and is directly taken from ecoinvent ${ }^{\circledR}$ as 
operation of a $28 \mathrm{t}$ truck with $100 \%$ rapeseed VOME. Operation of a $28 \mathrm{t}$ truck with fossil diesel is also taken from ecoinvent ${ }^{\circledR}$.

\section{Results}

The results for all impact categories are presented in Table 1 per kilogram of VOME for each unit process of the Argentinean case, modelled from feedstock production up to the exportation port.

Figure 2 shows the comparison of the AR case with the biodiesel and fossil diesel reference cases, including transport to Swiss border, distribution and use as B100 in $28 \mathrm{t}$ trucks in Switzerland. The contribution of each unit process of fuel production is also presented in Fig. 2 per kilometre.

Results for each impact category for $1 \mathrm{~km}$ driven in a $28 \mathrm{t}$ truck in Switzerland with B100 produced in AR from soybeans are: GWP, $1.2 \mathrm{~kg} \mathrm{CO}$-eq; CED, 9.6 MJ-eq; EP, 4 g PO 4 -eq; AP, 9 g SO -eq; TE, $1 \mathrm{~kg}$ 1,4-DCB-eq, AE, $2.2 \mathrm{~kg}$ 1,4-DCB-eq; HT, $0.4 \mathrm{~kg}$ 1,4-DCB-eq; LU, $1.8 \mathrm{~m}^{2} \mathrm{a}$.

Inputs and outputs contribution to the final results for all impact categories, expressed as percentage of the total impact, are presented in Table 2.

\subsection{Global warming potential and cumulative energy demand}

The impact of biodiesel production is highly dominated by the agricultural phase, especially in the cases of Argentina, Brazil, the EU, Switzerland and Malaysia. Feedstock production represents $61 \%, 66 \%, 62 \%, 57 \%$ and $47 \%$ of the CED, respectively. For the GWP, the contribution of feedstock production is even more significant, accounting for $80 \%, 83 \%, 79 \%, 83 \%$ and $62 \%$, respectively. However, for the US case, whilst the industrial phase is dominant in the CED (63\%), soybean production represents $54 \%$ of the GWP. GWP of biodiesel production in AR and BR is higher than the fossil reference and consequently is not a good choice to mitigate global warming. All biofuel pathways are below the fossil reference with respect to the CED, the AR case being the most energy-consuming one. The US has the best performance on GWP and CED.

The agricultural phase in Argentinean biodiesel production performs like the Brazilian one with respect to the CED and the GWP. The factors that explain the CED and the GWP values for the agricultural phase differ depending on the type of feedstock and the country of origin. When land use change occurs, like in Brazil, Malaysia and Argentina, the provision of land accounts for a significant part of the impact (Fargione et al. 2008; Searchinger et al. 2008; Righelato and Spracklen 2007; Kløverpris et al. 2008; Zah et al. 2007; Kløverpris et al. 2007). The high impact factors of Brazilian and Argentinean soybeans are mainly due to emissions from land use change. Provision of scrubbed land is an energy-intensive process that represents $83 \%, 51 \%$ and $55 \%$ of the CED, respectively, during the agricultural phase. When no land use change occurs, the CED is mainly determined by the harvesting process, the ploughing process, the production and use of fertilisers and the production of seeds, as in the cases of US, EU and $\mathrm{CH}$. Significant contribution to the impacts is due to the transesterification process ( $24 \%$ of the CED for the AR case), primarily due to the use of methanol. Biodiesel production requires $110.5 \mathrm{~kg}$ methanol per ton soybean oil. Nevertheless, the same input quantity was assumed for all the systems modelled, and consequently, methanol is not a parameter in the comparison of biodiesel pathways.

Table 1 Unit processes contribution to each impact category for the AR case, expressed in kilograms of soybean-based VOME and modelled from feedstock production at farm to VOME transport at port

\begin{tabular}{|c|c|c|c|c|c|c|}
\hline $\begin{array}{l}\text { Impact } \\
\text { category }\end{array}$ & $\begin{array}{l}\text { Unit Process } \\
\text { System } \\
\text { boundary } \\
\text { Units }\end{array}$ & $\begin{array}{l}\text { Feedstock } \\
\text { production } \\
\text { Farm }\end{array}$ & $\begin{array}{l}\text { Vegetable oil } \\
\text { extraction } \\
\text { Oil mill }\end{array}$ & $\begin{array}{l}\text { Transesterification } \\
\text { (VOME production) } \\
\text { Esterification plant }\end{array}$ & $\begin{array}{l}\text { VOME transport to } \\
\text { national port } \\
\text { National port }\end{array}$ & Total \\
\hline GWP & $\mathrm{kg} \mathrm{CO}$-eq & 3.5 & 0.2 & 0.4 & 0.0 & 4.0 \\
\hline CED & MJ-eq & 22.1 & 2.8 & 8.7 & 0.3 & 33.8 \\
\hline $\mathrm{EP}$ & $\mathrm{g} \mathrm{PO}_{4}$-eq & 11.0 & 0.1 & 0.3 & 0.0 & 11.5 \\
\hline $\mathrm{AP}$ & $\mathrm{g} \mathrm{SO}_{2}$-eq & 10.9 & 0.8 & 1.9 & 0.1 & 13.8 \\
\hline $\mathrm{TE}$ & kg 1,4-DCB-eq & 3.7 & 0.0 & 0.0 & 0.0 & 3.7 \\
\hline $\mathrm{AE}$ & $\mathrm{kg} 1,4-\mathrm{DCB}-\mathrm{eq}$ & 8.4 & 0.0 & 0.0 & 0.0 & 8.4 \\
\hline HT & $\mathrm{kg} 1,4-\mathrm{DCB}-\mathrm{eq}$ & 1.2 & 0.0 & 0.1 & 0.0 & 1.2 \\
\hline LU & $\mathrm{m}^{2} \mathrm{a}$ & 6.7 & 0.0 & 0.0 & 0.0 & 6.8 \\
\hline
\end{tabular}

$G W P$ global warming potential, $C E D$ cumulative energy demand, $E P$ eutrophication potential, $A P$ acidification potential, $T E$ terrestrial ecotoxicity, $A E$ aquatic ecotoxicity, $H T$ human toxicity, $L U$ land use competition, VOME vegetable oil methyl ester 


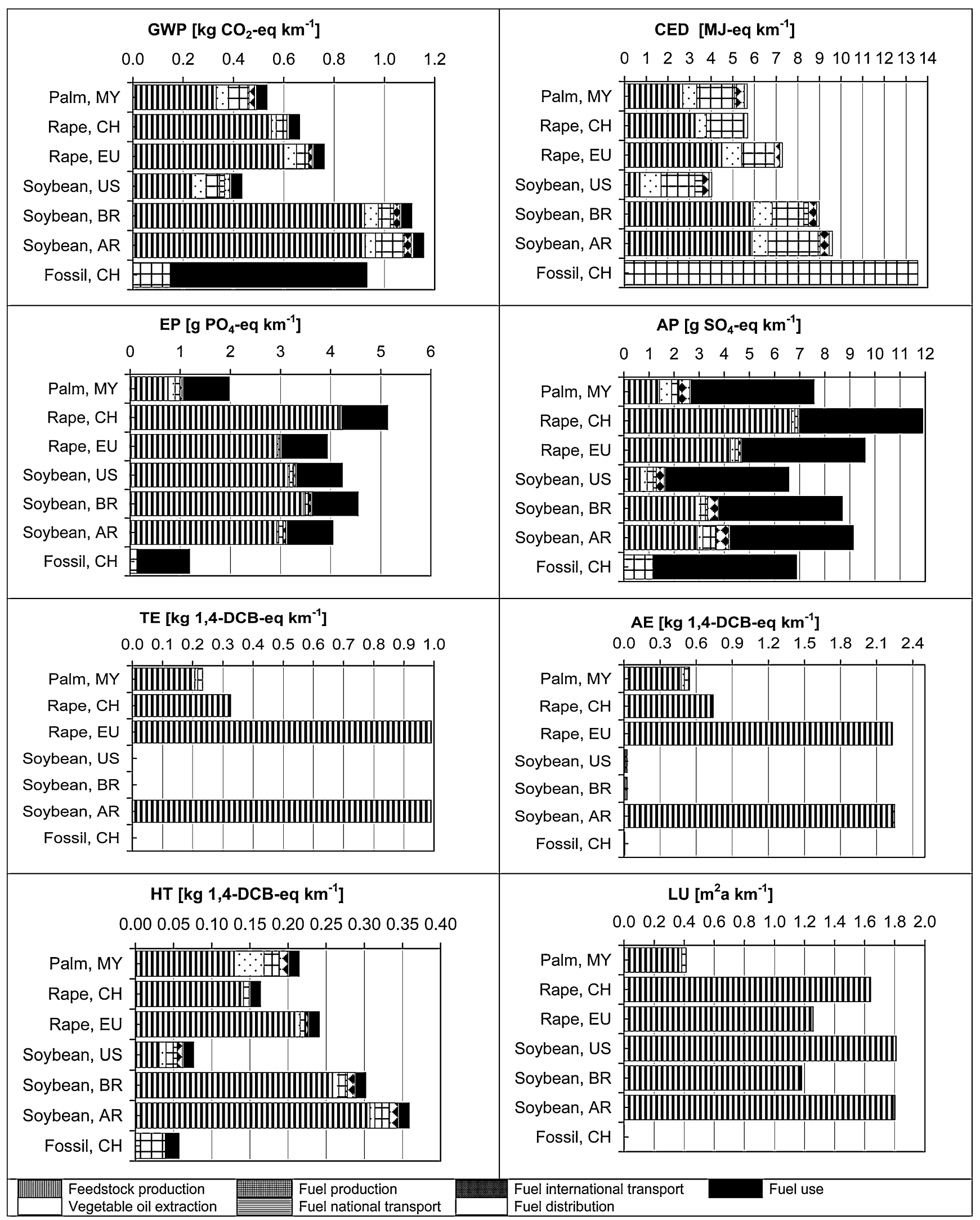

GWP: Global Warming Potential, CED: Cumulative Energy Demand, EP: Eutrophication Potential, AP: Acidification Potential, TE: Terrestrial Ecotoxicity, AE: Aquatic Ecotoxicity, HT: Human Toxicity, LU: Land Use Competition, MY: Malaysia, CH: Switzerland, EU: European Union, BR: Brazil, AR: Argentina.

Fig. 2 Comparison of the AR case with the reference biofuel and fossil pathways for each impact category 
Table 2 Main factors contributing to the environmental impact of soybean-based VOME production in AR and used as B100 in CH, expressed as percentage of the total impact

\begin{tabular}{|c|c|c|c|c|c|c|c|c|c|}
\hline Inputs/outputs & Unit process & GWP (\%) & CED (\%) & EP $(\%)$ & $\mathrm{AP}(\%)$ & TE $(\%)$ & $\mathrm{AE}(\%)$ & HT (\%) & LU (\%) \\
\hline Ammonia, in air & FP & 0 & 0 & 6 & 13 & 0 & 0 & 0 & 0 \\
\hline $\begin{array}{l}\text { Carbon dioxide, land transformation, } \\
\text { in air }\end{array}$ & $\mathrm{FP}$ & 16 & 0 & 0 & 0 & 0 & 0 & 0 & 0 \\
\hline Cypermethrin, in soil & $\mathrm{FP}$ & 0 & 0 & 0 & 0 & 100 & 97 & 16 & 0 \\
\hline Dinitrogen monoxide, in air & FP & 13 & 0 & 0 & 0 & 0 & 0 & 0 & 0 \\
\hline heat, at industrial furnace & VOE & 6 & 10 & 0 & 3 & 0 & 0 & 3 & 0 \\
\hline methanol, at plant & VOE & 2 & 12 & 0 & 0 & 0 & 0 & 1 & 0 \\
\hline Nitrate, in ground water & FP & 0 & 0 & 52 & 0 & 0 & 0 & 0 & 0 \\
\hline Nitrogen oxides, in air & $\mathrm{U}$ & 0 & 0 & 22 & 54 & 0 & 0 & 2 & 0 \\
\hline Occupation, arable, non-irrigated & FP & 0 & 0 & 0 & 0 & 0 & 0 & 0 & 97 \\
\hline provision, stubbed land & FP & 45 & 51 & 5 & 12 & 0 & 0 & 57 & 0 \\
\hline transport, lorry $20-28 \mathrm{t}$, fleet average & OP & 2 & 5 & 1 & 2 & 0 & 0 & 1 & 0 \\
\hline transport, transoceanic tanker & TB & 2 & 3 & 1 & 4 & 0 & 0 & 3 & 0 \\
\hline Others & & 14 & 20 & 14 & 11 & 0 & 2 & 17 & 3 \\
\hline
\end{tabular}

GWP global warming potential, $C E D$ cumulative energy demand, $E P$ eutrophication potential, $A P$ acidification potential, $T E$ terrestrial ecotoxicity, $A E$ aquatic ecotoxicity, $H T$ human toxicity, $L U$ land use competition, $F P$ feedstock production, $V O E$ vegetable oil esterification, $O P$ oil production, $U$ utilisation, $T B$ transport to border

Amazonian deforestation for soybean cultivation in Brazil, tropical deforestation in Malaysia for palm tree production and deforestation of dry subtropical forest in Argentina for soybean cultivation significantly contribute to an increase in GHG emissions. Emissions due to land preparation for agricultural use (land provision) together with carbon stock changes due to land use change represents $70 \%, 77 \%$ and $69 \%$ of the GWP of the feedstock production process, respectively, in the $\mathrm{BR}, \mathrm{AR}$ and $\mathrm{MY}$ cases.

Apart from land use change emissions, $\mathrm{N}_{2} \mathrm{O}$ emission is the other major contributor to the GWP. Nitrous oxide emissions are mainly due to the use of N-based fertilisers in the EU, CH and MY cases for rapeseed and palm oil production. However, in the case of soybean production, $\mathrm{N}_{2} \mathrm{O}$ comes mainly from BNF. $\mathrm{N}_{2} \mathrm{O}$ emissions accounts for $16 \%, 53 \%, 38 \%, 22 \%, 75 \%$ and $16 \%$ of the GWP of the agricultural phase for Malaysia, Switzerland, the European Union, Brazil, the United States and Argentina, respectively.

The generalised use of reduced tillage methods in Argentina ( $88 \%$ of the total soybean cultivation) explains the lower use of fossil fuels in the agricultural phase. However, the USA case gives lower values mainly because deforestation does not occur and because of the higher crop yields in US soybean $\left(2,641 \mathrm{~kg} \mathrm{ha}^{-1}\right)$, the lower transport distances and the lower use of pesticides in the agricultural phase. The US logistic system is more efficient. In Switzerland and the European Union, the same explanation can be given. The use of fertilisers for soybean cultivation is lower in Brazil, whilst the use of pesticides is lower in
Argentina. Soybean yield in Brazil $\left(2,544 \mathrm{~kg} \mathrm{ha}^{-1}\right)$ is similar to that of the Argentinean case.

The transport to port phase is only significant in the case of US (9\%), as biodiesel is transported over $1,400 \mathrm{~km}$ by train and $100 \mathrm{~km}$ by truck to the port. Transport to the Swiss border is significant for the cases of US and MY (7\% and $7 \%$ of the CED, respectively, and $5 \%$ and $4 \%$ of the GWP, respectively), mainly influenced by the transport distances from the biodiesel-producing country to the service station in Switzerland. Transoceanic transport represents $43 \%, 27 \%, 65 \%$ and $57 \%$ of the CED and $43 \%, 27 \%, 67 \%$ and $55 \%$ of the GWP of the transport phase for the cases of BR, US, MY and AR, respectively. For the US, the main contribution is the rail transport of VOME from the production site to the exportation port (34\% and $31 \%$ of the CED and the GWP of the distribution and transport phase), followed by the transoceanic transport ( $21 \%$ and $22 \%$ of the CED and the GWP of the distribution and transport phase, respectively).

Comparing the environmental impact with the diesel (54.9 MJ-eq kg ${ }^{-1}$ ) and the low-sulphur diesel (55.1 MJ-eq $\mathrm{kg}^{-1}$ ) used in Switzerland, all the VOME pathways perform worse than the fossil references for almost all the categories, with the exception of CED and GWP (for some pathways). The GWP for diesel and low-sulphur diesel production are 0.59 and $0.60 \mathrm{~kg} \mathrm{CO}_{2}$-eq kg ${ }^{-1}$, respectively. However, emissions from the utilisation phase in fossil diesel are not compensated by the biogenic carbon uptake as in the case of biodiesel, significantly increasing the GWP of the fossil reference. Nonetheless, the AR and the BR cases results in higher GWP. 


\subsection{Eutrophication and acidification potential}

The eutrophication potential result is mainly due to feedstock production and the utilisation of the fuel for all cases $(72 \%$ and $22 \%$ for the AR case, respectively). The acidification potential is explained mainly by emissions of ammonia to air, nitrates leaching to ground water and land provision for soybean cultivation. Significant contribution of the utilisation phase ( $22 \%$ of the EP) is due to nitrogen oxide emissions to air at fuel combustion. Similar results are obtained for the AR, EU, BR and US cases. However, the EP of all biofuel pathways is higher than that of the fossil reference.

Acidification potential is mainly due to the utilisation phase (54\% of the AP) as a consequence of nitrogen oxide emissions $(54 \%$ of the utilisation phase). Significant contribution of the feedstock production is due to ammonia emissions to air in soybean cultivation and ammonia, nitrogen oxides and sulfur dioxide emissions during land provision. All biofuel pathways result in a higher AP compared with the fossil reference, with the exception of the US case.

The impact of the utilisation phase on the EP and the AP is the same for all the biofuel pathways, as it was assumed that they all have the same properties.

\subsection{Terrestrial, aquatic and human toxicity}

Terrestrial and aquatic ecotoxicity results in similar relative values when comparing biofuel pathways. Cypermethrin is a potent pyretroid-based pesticides used in rape production in $\mathrm{CH}$ and $\mathrm{EU}$, in palm oil production in $\mathrm{MY}$ and in soybean production in AR for caterpillar control. Similar amounts are used in the EU and AR cases. This compound is responsible for almost all the TE and the $\mathrm{AE}$ in all cases. In US and BR, other pesticides with lower toxicological impact are used, giving almost no effect on $\mathrm{TE}$ and $\mathrm{AE}$, similar to the fossil reference.

Human toxicity is $49 \%$ due to benzene emissions to air during land provision (57\% of the HT) and cypermethrin application for pest biological control in the agricultural phase $(16 \%$ of the HT). The same inputs are the cause of high HT results for BR (only benzene), EU (only cypermethrin) and MY. All biofuel pathways give higher impacts than the fossil reference.

\subsection{Land use competition}

Arable land occupation for soybean cultivation is the main source contributing to the LU impact. Results for AR are similar to US values, as most of the soybean is cultivated as first-class soybean, giving no place for a second crop in an annual basis. Land occupation for rape cultivation in $\mathrm{CH}$ and EU differs due to higher yield in EU. The BR case results in lower land occupation, as it was modelled as a second-class soybean. Obviously, the fossil reference performs better than the biofuel pathways.

\subsection{Co-products}

Impact results for the co-products of biodiesel production are given in Table 3 based on economic allocation. Additional co-products processing to obtain marketable products are considered. Soybean meal drying and glycerine refining are included, in coherence with allocation based on market prices.

The environmental impact of the products is determined by the allocation of the environmental burden between coproducts. Whilst palm kernel meal produced in MY has the best performance in almost all impact categories, soybean meal produced in AR results in the highest impacts. Whilst glycerine production in EU from rapeseed oil results in the highest impacts for almost all the categories, glycerine from soybean oil produced in AR is the best case.

\section{Discussion}

\subsection{Previous studies}

No previous LCAs were found for soybean-based biodiesel in Argentina. However, a default value of GWP is given by the English Renewable Transport Fuel Obligation (RTFO) to calculate GHG balance of imported biofuels (RFA 2008), including soybean-based biodiesel produced in Argentina. The conservative default value given by the RTFO is less than half the result of this study $\left(4 \mathrm{~kg} \mathrm{CO}_{2}\right.$-eq kg ${ }^{-1} \mathrm{VOME}$ at esterification plant compared to $1.8 \mathrm{~kg} \mathrm{CO}_{2}-\mathrm{eq} \mathrm{kg}^{-1}$ from the RTFO). This discrepancy may be attributed to emissions from land use change. However, no data was available about how the RTFO value was estimated.

Dalgaard et al. (2007) give values for GWP, AP and EP for soybean and soybean meal production in Argentina based on a consequential LCA approach. The GWP of Argentinean soybean obtained by Dalgaard et al. (2007) differs from the value obtained in this study $(0.6$ and $1.6 \mathrm{~kg}$ $\mathrm{CO}_{2}$-eq $\mathrm{kg}^{-1}$ soybean, respectively). GWP values for the AR soybean meal are between 0.3 and $0.7 \mathrm{~kg} \mathrm{CO}_{2}$-eq kg ${ }^{-1}$ depending on the reference system chosen for assigning the impacts under a system expansion approach. These differences are explained by the influence of the allocation method (system expansion vs. economic allocation) and due to different assumptions in the LCA inventory. Mainly, deforestation for soybean production (and consequently emissions from land use change) was not considered and no $\mathrm{N}$ fertiliser use was assumed by Dalgaard et al. (2007). 
However, BNF values are higher than in our study (132 kg $\mathrm{N} \mathrm{ha}^{-1}$ compared to $70 \mathrm{~kg} \mathrm{~N}^{-1}$ in our study). Dalgaard et al. (2007) reports positive and negative acidification values as a consequence of palm oil and rape meal substitution, respectively, in the system expansion approach, which results in an impact or a credit (avoided acidification) for soybean meal in Argentina. The values for soybean are 5 and $0.8 \mathrm{~g} \mathrm{SO}_{2}$-eq kg $\mathrm{kg}^{-1}$ soybean in this study and in Dalgaard et al. (2007) (both calculated through the EDIP method). This difference relies on the different $\mathrm{N}$ input assumed, on the estimation method for ammonia and nitrogen oxides and on the excluded nitrogen oxide emissions from land provision. Eutrophication values (negative in Dalgaard et al. and positive in our study) differ mainly because of the allocation method and because they have assumed no nitrate leaching to groundwater (responsible for $52 \%$ of the EP in our study).

Whilst Dalgaard et al. have modelled the soybean production system with punctual data for a specific year, we have used average data from a specific period whenever these data were available. This factor also contributes to explain the different results obtained.

\subsection{Sensitivity analysis}

Five scenarios were modelled to determine the impact of changing inputs in the agricultural and fuel production phase, corresponding to the following situations:

- S1 10\% increment in yield while keeping the same level of inputs and labour;

- S2 Avoiding deforestation;

- S3 Shift soybean production method;

- S4 Soybean inoculation with bacteria and BNF value;

- S5 Avoiding cypermethrin use;

- S6 Avoiding methanol use;

- $\quad$ S7 Glycerine price.

Results are compared with the Argentinean reference case and presented in Table 4 . The environmental impact of the system is mainly determined by the agricultural phase and, consequently, by the soybean yield in AR. The sensitivity analysis shows that an increase of $10 \%$ in the soybean yield by keeping the same inputs ( $\mathrm{S} 1)$ will reduce the GWP and the EP of B100soy ARG-CH $_{\text {in }} \mathrm{CH}$ by $7 \%$, the ecotoxicity and the LU by $9 \%$, the CED by $5 \%$ and the AP by $3 \%$, respectively. On the other hand, increasing the yield is likely to increase diesel consumption in harvesting (and possibly the use of fertilisers). For instance, considering a $46 \%$ increment in yield for soybean $(3,800 \mathrm{~kg}$ $\mathrm{ha}^{-1}$ ) diesel consumption will rise by $26 \%$ (Donato et al. 2005). A yield increment allows one to obtain lower values of the environmental indicators, resulting in lower impacts. 
Table 4 Sensitivity analysis of significant variables impacting the final results per kilometre

\begin{tabular}{|c|c|c|c|c|c|c|c|c|c|}
\hline \multirow[t]{2}{*}{ Scenario } & \multicolumn{9}{|l|}{ Description } \\
\hline & $\begin{array}{l}\text { Impact category } \\
\text { Units }\end{array}$ & $\begin{array}{l}\mathrm{GWP} \\
\mathrm{kg} \mathrm{CO}_{2} \text {-eq }\end{array}$ & $\begin{array}{l}\text { CED } \\
\text { MJ-eq }\end{array}$ & $\begin{array}{l}\mathrm{EP} \\
\mathrm{g} \mathrm{PO}_{4} \text {-eq }\end{array}$ & $\begin{array}{l}\mathrm{AP} \\
\mathrm{g} \mathrm{SO}_{2} \text {-eq }\end{array}$ & $\begin{array}{l}\text { TE } \\
\text { kg 1,4-DCB-eq }\end{array}$ & $\begin{array}{l}\mathrm{AE} \\
\mathrm{kg} \mathrm{1,4-DCB-eq}\end{array}$ & $\begin{array}{l}\text { HT } \\
\text { kg 1,4-DCB-eq }\end{array}$ & $\begin{array}{l}\mathrm{LU} \\
\mathrm{m}^{2} \mathrm{a}\end{array}$ \\
\hline S0 & Reference & 1.2 & 9.6 & 4.0 & 9.1 & 1.0 & 2.3 & 0.4 & 1.8 \\
\hline $\mathrm{S} 1$ & Yield increment & $\begin{array}{l}1.1 \\
-7 \%\end{array}$ & $\begin{array}{l}9.1 \\
-5 \%\end{array}$ & $\begin{array}{l}3.8 \\
-7 \%\end{array}$ & $\begin{array}{l}8.9 \\
-3 \%\end{array}$ & $\begin{array}{l}0.9 \\
-9 \%\end{array}$ & $\begin{array}{l}2.0 \\
-9 \%\end{array}$ & $\begin{array}{l}0.3 \\
-8 \%\end{array}$ & $\begin{array}{l}1.6 \\
-9 \%\end{array}$ \\
\hline $\mathrm{S} 2$ & Avoiding deforestation & $\begin{array}{l}0.4 \\
-61 \%\end{array}$ & $\begin{array}{l}4.7 \\
-51 \%\end{array}$ & $\begin{array}{l}3.9 \\
-5 \%\end{array}$ & $\begin{array}{l}8.0 \\
-12 \%\end{array}$ & $\begin{array}{l}1.0 \\
0 \%\end{array}$ & $\begin{array}{l}2.2 \\
0 \%\end{array}$ & $\begin{array}{l}0.2 \\
-57 \%\end{array}$ & $\begin{array}{l}1.8 \\
0 \%\end{array}$ \\
\hline $\mathrm{S} 3$ & FCRT & $\begin{array}{l}1.1 \\
-2 \%\end{array}$ & $\begin{array}{l}9.5 \\
-1 \%\end{array}$ & $\begin{array}{l}3.7 \\
-8 \%\end{array}$ & $\begin{array}{l}8.9 \\
-2 \%\end{array}$ & $\begin{array}{l}0.8 \\
-21 \%\end{array}$ & $\begin{array}{l}1.8 \\
-20 \%\end{array}$ & $\begin{array}{l}0.3 \\
-4 \%\end{array}$ & $\begin{array}{l}1.9 \\
7 \%\end{array}$ \\
\hline & FCCT & $\begin{array}{l}1.2 \\
1 \%\end{array}$ & $\begin{array}{l}9.8 \\
2 \%\end{array}$ & $\begin{array}{l}4.0 \\
-1 \%\end{array}$ & $\begin{array}{l}9.2 \\
1 \%\end{array}$ & $\begin{array}{l}2.5 \\
149 \%\end{array}$ & $\begin{array}{l}5.5 \\
146 \%\end{array}$ & $\begin{array}{l}0.5 \\
27 \%\end{array}$ & $\begin{array}{l}2.3 \\
26 \%\end{array}$ \\
\hline & SCRT & $\begin{array}{l}1.2 \\
2 \%\end{array}$ & $\begin{array}{l}9.5 \\
-1 \%\end{array}$ & $\begin{array}{l}4.5 \\
11 \%\end{array}$ & $\begin{array}{l}9.3 \\
2 \%\end{array}$ & $\begin{array}{l}0.2 \\
-84 \%\end{array}$ & $\begin{array}{l}0.4 \\
-83 \%\end{array}$ & $\begin{array}{l}0.3 \\
-15 \%\end{array}$ & $\begin{array}{l}1.4 \\
-22 \%\end{array}$ \\
\hline $\mathrm{S} 4$ & NBF value & $\begin{array}{l}1.2 \\
6 \%\end{array}$ & $\begin{array}{l}9.6 \\
0 \%\end{array}$ & $\begin{array}{l}5.1 \\
27 \%\end{array}$ & $\begin{array}{l}9.7 \\
7 \%\end{array}$ & $\begin{array}{l}1.0 \\
0 \%\end{array}$ & $\begin{array}{l}2.3 \\
0 \%\end{array}$ & $\begin{array}{l}0.4 \\
0 \%\end{array}$ & $\begin{array}{l}1.8 \\
0 \%\end{array}$ \\
\hline & Rhizobacteria inoculation & $\begin{array}{l}1.0 \\
-13 \%\end{array}$ & $\begin{array}{l}8.3 \\
-14 \%\end{array}$ & $\begin{array}{l}4.2 \\
5 \%\end{array}$ & $\begin{array}{l}9.0 \\
-2 \%\end{array}$ & $\begin{array}{l}0.8 \\
-22 \%\end{array}$ & $\begin{array}{l}1.7 \\
-22 \%\end{array}$ & $\begin{array}{l}0.3 \\
-19 \%\end{array}$ & $\begin{array}{l}1.4 \\
-22 \%\end{array}$ \\
\hline S5 & Avoiding cypermethrin use & $\begin{array}{l}1.2 \\
0 \%\end{array}$ & $\begin{array}{l}9.6 \\
0 \%\end{array}$ & $\begin{array}{l}4.0 \\
0 \%\end{array}$ & $\begin{array}{l}9.1 \\
0 \%\end{array}$ & $\begin{array}{l}0.0 \\
-100 \%\end{array}$ & $\begin{array}{l}0.1 \\
-97 \%\end{array}$ & $\begin{array}{l}0.3 \\
-16 \%\end{array}$ & $\begin{array}{l}1.8 \\
0 \%\end{array}$ \\
\hline S6 & Avoiding methanol use & $\begin{array}{l}1.1 \\
-1 \%\end{array}$ & $\begin{array}{l}8.6 \\
-11 \%\end{array}$ & $\begin{array}{l}4.1 \\
1 \%\end{array}$ & $\begin{array}{l}9.3 \\
1 \%\end{array}$ & $\begin{array}{l}1.0 \\
0 \%\end{array}$ & $\begin{array}{l}2.3 \\
0 \%\end{array}$ & $\begin{array}{l}0.4 \\
23 \%\end{array}$ & $\begin{array}{l}1.9 \\
3 \%\end{array}$ \\
\hline S7 & Glycerine price & $\begin{array}{l}1.1 \\
-6 \%\end{array}$ & $\begin{array}{l}9.0 \\
-6 \%\end{array}$ & $\begin{array}{l}3.8 \\
-5 \%\end{array}$ & $\begin{array}{l}8.9 \\
-3 \%\end{array}$ & $\begin{array}{l}0.9 \\
-7 \%\end{array}$ & $\begin{array}{l}2.1 \\
-7 \%\end{array}$ & $\begin{array}{l}0.3 \\
-6 \%\end{array}$ & $\begin{array}{l}1.7 \\
-7 \%\end{array}$ \\
\hline
\end{tabular}

GWP global warming potential, $C E D$ cumulative energy demand, $E P$ eutrophication potential, $A P$ acidification potential, $T E$ terrestrial ecotoxicity, $A E$ aquatic ecotoxicity, $H T$ human toxicity, $L U$ land use competition, $F C R T$ first-class soybean in reduced tillage, $S C R T$ second-class soybean in reduced tillage, FCCT first-class soybean in conventional tillage

Avoiding deforestation (S2) and allocating the future land expansion to other set-aside and marginal arable land significantly decreases the environmental performances of the system, as follows: GWP is reduced by $61 \%$ as $\mathrm{CO}_{2}$ emissions from soil and biomass are avoided; CED decreases on $51 \%$ as biomass energy use from primary forest is avoided; AP is reduced by $12 \%$ as ammonia, nitrogen oxides and sulfur dioxide emissions are avoided; HE decreases on $57 \%$ as benzene emissions are avoided; EP is reduced on 5\% for avoided ammonia and nitrogen oxides emissions during land provision. No effect on TE and $\mathrm{AE}$ occurs and an insignificant increase on $\mathrm{LU}$ is obtained. Deforestation for soybean cultivation was assumed to be $64 \%$ of the deforested area in the Northern provinces of Argentina. However, other land use changes have occurred due to soybean expansion, such as conversion of other cropland (mainly wheat, corn, sunflower and sorghum) and conversion of pastureland (Pengue 2006). A default value of $0.05 \mathrm{~kg} \mathrm{CO}_{2}$-eq $\mathrm{kg}^{-1}$ of biodiesel is given by the RTFO for grassland conversion (RFA 2008). Nevertheless, consistent data to account for these changes were not available. Uncertainty is linked to carbon emissions, as the used data were estimated as accumulated emissions. Consequently, the emissions do not only account for the carbon loss of a specific year but also for the decaying emission of previous years calculated during 25 years. This has resulted in an overestimation of the emissions in an annual basis.

The soybean production method has a strong influence on the results (S3). When shifting to conventional tillage, the ecotoxicity of the system increased significantly, mainly for $\mathrm{TE}$ and $\mathrm{AE}$, due to the higher input of cypermethrin and the lower yields in conventional soybean production. LU is also increased, as FCCT soybean production does not allow crop succession. When shifting to reduced tillage methods, the impact of the system is reduced. FCRT soybean production allows reducing the ecotoxicity impact due to a reduction in cypermethrin input and reducing GWP and CED due to lower diesel consumption in agricultural processes. SCRT method allows reducing the ecotoxicity effect for the same reason and the LU due to soybeanwheat succession whilst EP is increased.

Soybean production in AR, BR and US was modelled with a $\mathrm{N}$ fixation value of $70 \mathrm{~kg} \mathrm{ha}^{-1}$. However, the BNF depends on the $\mathrm{N}$ content in the grain, the type of soil and the agricultural practices in each country, and consequently, different values are expected to be obtained in each country and production system. For the AR case, BNF varies 
between 80 and $120 \mathrm{~kg} \mathrm{ha}^{-1}$ (Díaz Zorita 2003; Racca 2002), and reduced tillage systems allow fixing more $\mathrm{N}$ than conventional tillage systems (González 2007). BNF values of $120,80,100$ and $70 \mathrm{~kg} \mathrm{~N} \mathrm{ha}^{-1}$ are assumed for FCRT, SCRT, FCCT and SCCT, respectively (S4). BNF values are estimated in function of crop yields and as $50 \%$ of the soybean $\mathrm{N}$ requirements (Melgar, personal communication). The new BNF values have mainly increased the EP. Soybean inoculation with rhizobacteria allows increasing BNF and this results in reducing fertiliser inputs and increasing yield. A yield increment between 500 and $1,000 \mathrm{~kg} \mathrm{ha}^{-1}$ can be obtained (González 2007). This variable was added assuming a yield increment of $750 \mathrm{~kg} \mathrm{ha}^{-1}$ and the new BNF values. Even though $\mathrm{N}_{2} \mathrm{O}$ emissions per hectare are increased as more $\mathrm{N}$ is fixed, they are compensated by the increased yield, resulting in a reduction of the environmental impact. Because assuming other BNF values would have resulted in an overestimation of the $\mathrm{N}_{2} \mathrm{O}$ emissions in the Argentinean case, compared with the reference soybean-based biodiesel pathways, the same assumption was used in this study.

Cypermethrin use can be avoided by replacing it by deltamethrin, another pyretroid-based pesticide use in AR (S5). The ecotoxicity of deltamethrin is significantly lower than that of cypermethrin, resulting in reduction of the TE, the AE and the HT of $100 \%, 97 \%$ and $16 \%$, respectively.

An alternative to reduce CED from methanol use is to substitute it by bioethanol (3.6 MJ-eq $\mathrm{kg}^{-1}$ Brazilian sugarcane-based ethanol (Jungbluth et al. 2007) compared to $37.4 \mathrm{MJ}$-eq $\mathrm{kg}^{-1}$ methanol; S6). Using ethanol as the alcohol in the transesterification reaction can significantly improve the energy balance of the Argentinean pathway when this is proven technically feasible. When importing BR sugarcane-based ethanol, including $1,000 \mathrm{~km}$ transport in $28 \mathrm{t}$ trucks from fermentation plant to the port of Foz do Iguaçu, 1,000 km transport by barge tanker to the Rosario port and $100 \mathrm{~km}$ transport in $28 \mathrm{t}$ truck to the esterification plant, the CED decreases by $11 \%$. Nonetheless, HT is increased due to emissions to air during bioethanol transport. Domestic ethanol production can significantly reduce this impact.

Best case includes higher productivity, no deforestation, reduced tillage, soybean inoculation, avoiding cypermethrin use and avoiding methanol use in VOME transesterification. These measures should be undertaken in order to make AR biodiesel more environmentally competitive.

Sensitivity analysis of allocation methods (economic, mass, energy and carbon content) did not result in significant differences for the Argentinean case nor for the reference cases. The different vegetable oil extraction yield and the higher oil content for rapeseed and palm fruit bunches in the EU, CH and MY (397 and $380 \mathrm{~kg}$ oil per ton rapeseed and $242 \mathrm{~kg}$ oil per ton palm fruit bunches, respectively) than for soybean in AR, BR and the US (182, 182 and $188 \mathrm{~kg}$ oil per ton soybean) determines different allocation factors and consequently contributes to explain the different results.

Allocation of glycerine results for AR was based on national market price (US\$0.1 per kilogram of glycerine). The reference cases were modelled assuming higher prices (US\$0.66 per kilogram in the US and BR, US\$1.66 per kilogram in $\mathrm{CH}$, the $\mathrm{EU}$ and $\mathrm{MY}$ ). The impact factors for glycerine are highly influenced by the low market value of commercial glycerine in Argentina. Increased production of biodiesel may generate export opportunities for glycerine. Performing the allocation based on US glycerine market price (S7) results in a $500 \%$ increase in the environmental impact of glycerine (results are similar to those of the BR case for GWP, CED, EP, AP and LU and similar to the EU case for ecotoxicity effects) and an average decrease of $6 \%$ of the impact of B100soy ARG-CH $_{\text {for }}$ foll categories. Consequently, even though the allocation method did not significantly affect the result, the price variation in economic allocation has a strong impact.

The impact of transportation and utilisation phase is a function of transport distance and the type of vehicle used in each country. When biodiesel is intended to be exported to other country, the values "at Port" in Table 1 should be used and the impact of the transport and distribution to the chosen country and the assumptions related to the utilisation phase should be added.

The AR case was modelled with a higher level of detail than the reference cases, especially in the agricultural phase where four different production systems were considered. As shown in the sensitivity analysis, when assuming one production system for all soybean production, results are significantly modified.

\section{Conclusions}

Argentinean biodiesel producers will need to study the environmental performance of their products in order to comply with sustainability criteria being developed (Farrell and Sperling 2007a, b; Bauen et al. 2007; Cramer et al. 2007). Due to the potential of Argentina to produce biodiesel for export, this work constitutes a baseline to analyse the environmental impact of this feedstock and country-specific pathway by estimating the energy consumption, the GHG emissions, the acidification and the eutrophication potentials, the ecotoxicity effects and the land use competition of soybean-based biodiesel production in Argentina for export. The position of Argentina as a soybean-based biodiesel exporter is proven to be not competitive from the environmental point of view unless 
specific measures are undertaken. These measures include avoiding deforestation, applying reduced tillage and crops successions, applying soybean inoculation methods, increasing yield, using low ecotoxicity pesticides and using biomass-based methanol or bioethanol in VOME production. Compared with the fossil reference, the AR pathway has a worse performance in all the impact categories with the exception of energy consumption. The analysis of the explanatory factors shows the significant influence of the land use change, the BNF and the use of fertilisers, the applied pesticides, the soybean production method, the use of methanol and the transport system in the environmental impact.

\section{Recommendations and perspectives}

\subsection{Modelling approach}

Modelling of the agricultural phase is still too rigid. More efforts should be conducted to account for interactions between input and output variables (e.g. the impact of previous crop management, the correlation between application of fertilisers and yield increment, the influence of soybean inoculation on $\mathrm{N}_{2} \mathrm{O}$ emissions, the relation between tillage method and fertiliser use). Better knowledge of these correlations will allow improving agricultural phase modelling.

Better accounting for land use changes, interaction between variables and previous crops in the agricultural phase, future transesterification technologies and market prices evolution are essential to improve modelling of biofuel pathways.

Soybean in Argentina is cultivated as monoculture as well as in rotation with wheat. The management of the previous crop will have an impact on the subsequent soybean culture. Nitrogen fertiliser was allocated to the crop to which it was applied. No residual effect to the secondary crop was considered. However, in reality, second-class soybean, cultivated after wheat, is not additionally fertilised as it uses the residual $\mathrm{N}$ from the wheat fertilisation. Similar consequences may apply to the use of pesticides and the choice of the tillage method. Expanding the system to account for crops succession will help to better model the system inputs in the agricultural phase. Moreover, the development of new transesterification technologies, the choice of additives and process optimisation may influence the impact of the system on the environment.

The level of detail of data inputs should be improved in order to better account for regional specificities and to generate consistent average data at the national level. Nonetheless, more efforts should be conducted to harmonise LCA methodology for biofuel impact assessment in order to allow comparison between biofuel pathways.

The values for the fossil reference system are actually 'black box' results. However, the same modelling concerns (i.e. allocation method) of the biofuel pathways applied to the fossil reference (Guinée and Heijungs 2007). Further efforts are needed in this issue.

Based on the LASEN Biofuel's Platform, perspectives include the study of modelling choices in this pathway, the integration of agricultural models and the improvement of the LCI data especially for the oil extraction and transesterification phases.

Carbon emissions from deforestation should be better accounted for when new data become available.

\subsection{Data uncertainty}

The process of land provision from deforestation should be characterised for the AR case. Soybean cultivation data on deforested areas should be improved and become more consistent, including the amount of soybean cultivated in deforested land, soybean cultivation period, soybean yields and the applied agricultural practices.

Grain drying is identified as an important contributor in the rapeseed-based reference systems. This process should be better modelled when more data become available. Data on transesterification process should be developed and data on oil production should be improved.

In order to assess more accurately biodiesel production pathways, further consideration should be given to include indirect land use changes. For example, US soybean is produced in rotation with corn, and so, increased corn acreage in US will reduce soybean production and increase soybean price. This may be encouraging soybean expansion in $\mathrm{AR}$ and $\mathrm{BR}$ and consequently encouraging deforestation processes in these countries. However, an attributional LCA can not capture this kind of effects and further research is needed to determine and allocate indirect land use changes to a biofuel pathway.

Data on soybean production methods and agricultural practices should be harmonised, georeferenced and officially validated. Data at the county level should be developed, integrated and become consistent with national average values to account for production scale effects and logistical constraints in biodiesel production.

Acknowledgements We kindly acknowledge Luciana Moltoni and Jorge Hilbert from the Institute of Rural Engineering at the National Institute of Agricultural Technology in Argentina (IIR-INTA) for data provision. We are grateful to Andres Leone from the National Biofuels Program at the Secretary of Agriculture, Livestock, Fishery and Food (SAGPyA) in Argentina for his useful comments and Ignacio Gasparri 
from the University of Tucumán (LIEY-CONICET) for providing data and validating hypotheses on deforestation and land use change emissions. Finally, we are grateful to anonymous reviewers for their useful remarks to improve this paper.

\section{References}

ADEME (2002) Bilans énergétiques et gaz à effet de serre des filières de production des biocarburants, rapport technique. ADEME, DIREM, PriceWaterhouseCoopers

Asal S, Marcus R (2005) An analysis of the obstacles to the development of a sustainable biodiesel industry in Argentina. Report. Université Paris-Dauphine. DU-Développement Durable \& Organisations

Bauen A, Watson P, Howes J (2007) Carbon reporting within the renewable transport fuel obligation: methodology. E4tech

Benbrook CM (2005) Rust, resistance, run down soils and rising costsproblems facing soybean producers in Argentina. Ag Biotech InfoNet, Technical Paper no. 8. 20 January 2005

Bernesson S, Nilsson D, Hansson PA (2004) A limited LCA comparing large- and small-scale production of rape methyl ester (RME) under Swedish conditions. Biomass Bioenerg 26:545559

Cramer J et al (2007) Testing framework for sustainable biomass. Final report from the project group 'Sustainable production of biomass'. Creative Energy

Ciani R, Esposito A (2005) Perfil descriptivo de la cadena de oleaginosos. SAGPyA. Available at: http://www.sagpya.gov.ar. Accessed 15 December 2006 (in Spanish)

CONCAWE-EUCAR-JRC (2007) Well-to-wheels analysis of future automotive fuels and powertrains in the European context. Wellto-wheels report, version 2c. Available at: http://ies.jrc.cec.eu.int/ wtw.html. Accessed 10 March 2008

Dalgaard R, Schmidt J, Halberg N, Christensen P, Thrane M, Pengue WA (2007) LCA of soybean meal. Int J Life Cycle Assess 13 (3):240-254

Díaz Zorita, M (2003) Nuevas estrategias en el manejo de la soja. Fertilización en soja en Argentina. En: Simposio internacional sobre soja. XI Congreso Nacional de AAPRESID. Tomo 2. pp $113-127$

Donato L, Moltoni L, Hilbert J (2005) La producción de biocombustibles empleando siembra directa en la Argentina: Implicancias económicas y energéticas. Instituto de Ingeniería Rural-INTA (in Spanish)

Elsayed MA, Matthews R, Mortimer ND (2003) Carbon and energy balances for a range of biofuels options. Project No. B/B6/00784/ REP URN 03/836. Available at: http://www.berr.gov.uk/files/ file14925.pdf. Accessed 10 March 2008

Fargione J, Hill J, Tilman D, Polasky S, Hawthorne P (2008) Land clearing and the biofuel carbon debt. Science 319(5867):12351238

Farrell AE, Plevin RJ, Turner BT, Jones AD, O'Hare M, Kammen DM (2006) Ethanol can contribute to energy and environmental goals. Science 311(5781):506-508

Farrell AE, Sperling D (2007a) A low-carbon fuel standard for California, Part 1: technical analysis. University of California

Farrell AE, Sperling D (2007b) A low-carbon fuel standard for California, part 2: policy analysis. University of California

Food and Agriculture Organization of rhe United Nations (2004) Fertilizer use by crop in Argentina. Land and Plant Nutrition Management Service, Land and Water Development Division, Rome

Franco D (2005a) Aceite de soja: Análisis de Cadena Alimentaria. SAGPyA. Available at: http://www.alimentosargentinos.gov.ar. Accessed 15 December 2006 (in Spanish)
Franco D (2005b) Logística en la cadena de oleaginosas. SAGPyA, Dirección de Industria Alimentaria. Revista Alimentos Argentinos $\mathrm{N}^{\circ}$ 30, Oct. 2005. Available at: http://www.alimentosargentinos. gov.ar. Accessed 8 December 2006 (in Spanish)

Frischknecht R (2005) Ecoinvent data v1.1 (2004): from heterogenous databases to unified and transparent LCI data. Int J Life Cycle Assess 10(1):1-2

Frischknecht R, Jungbluth N, Althaus HJ, Doka G, Dones R, Heck T, Hellweg S, Hischier R, Nemecek T, Rebitzer G, Spielmann M (2004) The ecoinvent database: overview and methodological framework. Int J Life Cycle Assess 10(1):3-9

Gasparri NI, Grau H, Manghi E (2008) Carbon pools and emissions from deforestation in extra-tropical forests of northern Argentina between 1900 and 2005. Ecosystems 11:1247-1261

Gasparri NI, Manghi E (2004) Estimación de volumen, biomasa y contenido de carbono de las regions forestales argentines. Informe final, Unidad de Manejo del Sistema de Evaluación Forestal, Dirección de bosques, Secretaría de ambiente y desarrollo sustentable, Septiembre 2004 (in Spanish)

GM-LBST (2002) GM Well-to-wheel analysis of energy use and greenhouse gas emissions of advanced fuel/vehicle systems: a European study. General Motors, L-B-Systemtechnik

Gnansounou E, Dauriat A (2005) Energy balance of bioethanol: a synthesis. Proceedings of the 14th European Biomass Conference \& Exhibition, Paris, France, Oct. 2005

Gnansounou E, Dauriat A, Panichelli L, Villegas JD (2008) Energy and greenhouse gas balances of biofuels: biases induced by LCA modelling choices. J Sci Ind Res (JSIR) 67:885-897

González N (2007) Fijación de Nitrógeno en soja. Uso de inoculantes. Available at: http://www.planetasoja.com/trabajos/trabajos800. php?id $1=3277 \& \mathrm{id} 2=3278 \& \mathrm{idSec}=26$. Accessed 22 February 2008 (in Spanish)

Grau HR, Gasparri NI, Aide TM (2005) Agriculture expansion and deforestation in seasonally dry forests of north-west Argentina. Environ Conserv 32(2):140-148

Guinée JB, Heijungs R (2007) Calculating the influence of alternative allocation scenarios in fossil fuel chains. Int J Life Cycle Assess 12(3):173-180

Houghton RA (2003) Revised estimates of the annual net flux of carbon to the atmosphere from changes in land use and land management 1850-2000. Tellus 55B(2):378-390

IDIED (2004) Instituto de Investigación en Economía y Dirección para el Desarrollo, Universidad Austral. Indicadores económicos regionales, Septiembre 2004. Available at: http://www.austral. edu.ar/FCE/inst idied.htm. Accessed 8 December 2006 (in Spanish)

ISO (2006a) Norma ISO 14040:2006. Environmental management. Life cycle assessment. Principles and framework

ISO (2006b) Norma ISO 14044:2006. Environmental management. Life cycle assessment. Requirements and guidelines

Johnston M, Holloway T (2007) A global comparison of national biodiesel production potentials. Environ Sci Technol 41:23

Jungbluth N, Faist Emmenegger M, Dinkel F, Stettler O, Doka G, Chudacoff M, Dauriat A, Gnansounou E, Sutter J, Spielmann M, Kljun N, Schleiss K (2007) Life cycle inventories of bioenergy. Data v2.0 (2007), ecoinvent report No. 17, Swiss Center for Life Cycle Inventories, Uster

Kløverpris J, Wenzel H, Nielsen PH (2007) Life cycle inventory modelling of land use induced by crop consumption. Part 1: conceptual analysis and methodological proposal. Int $\mathrm{J}$ Life Cycle Assess 13(1):13-21

Kløverpris J, Wenzel H, Banse M, Milà i Canals L, Reenberg A (2008) Conference and Workshop on Modelling Global Land Use Implications in the Environmental Assessment of Biofuels. Int J Life Cycle Assess 13(3):178-183 
Márgenes agropecuarios (2006) Costos y márgenes de producción para soja de primera y soja de segunda. Revista Márgenes Agropecuarios, 2/10/06, pp 57-59 (in Spanish)

Montenegro C, Strada M, Bono J, Gasparri NI, Manghi E, Parmuchi MG, Brouver M (2005) Estimación de la pérdida de superficie de bosque nativo y tasa de deforestación en el norte de argentina. 3er congreso forestal argentino y latinoamericano 6-9 Septiembre 2005, Corrientes (in Spanish)

Nemecek T, Heil A, Huguenin O, Meier S, Erzinger S, Blaser S, Dux D, Zimmermann A (2007) Life Cycle Inventories of Agricultural Production Systems. ecoinvent report No. 15, v2.0. Agroscope FAL Reckenholz and FAT Taenikon, Swiss Centre for Life Cycle Inventories, Dübendorf

Paruelo JM, Guerschman JP, Verón SR (2005) Expansión agrícola y cambios en el uso del suelo. CienciaHoy Bs As 15(87):14-23 (in Spanish)

Pengue WA (2005) Transgenic crops in Argentina: the ecological and social debt. Bull Sci Technol Soc 25(NA):1-9

Pengue WA (2006) Increasing roundup ready soybean export from Argentina. In: Trydeman Knudsen M, Halberg N, Olesen JE, Byrne J, Iyer V, Toly N (eds) Global trends in agriculture and food systems. CEEP Publications, USA

Racca R (2002) Fijación biológica del nitrógeno. In: Actas 1er Simposio de Fertilidad de Suelos y Fertilización en Siembra Directa, X Congreso Nacional de AAPRESID, pp 197-208 (in Spanish)

Reijnders L, Huijbregts MAJ (2008) Palm oil and the emission of carbon-based greenhouse gases. J Clean Prod 16:477-482

RFA (2008) Carbon and sustainability reporting within the renewable transport fuel obligation. Technical Guidance, Office of the Renewable Fuels Agency

Righelato R, Spracklen DV (2007) Carbon mitigation by biofuels or by saving and restoring forests. Science 317(5840):902-902

Russi D (2008) An integrated assessment of a large-scale biodiesel production in Italy. Energ Policy 36:1169-1180
SAGPyA-IICA (2005) Secretaria de Agricultura, Ganadería, Pesca y Alimentos-Instituto Interamericano de Cooperación para la Agricultura. Perspectivas de los biocombustibles en la Argentina y en Brasil. Documento no. ISBN: 987-9159-07-1

SAGPyA (2006a) Estimaciones agrícolas. Available at: http://www. sagpya.gov.ar. Accessed 15 December 2006 (in Spanish)

SAGPyA (2006b) Panorama del uso y consumo de fertilizantes en Argentina. Available at: http://www.sagpya.mecon.gov.ar. Accessed 15 December 2006 (in Spanish)

SAGPyA (2006c) Evolución de los precios externos de oleaginosos. Available at: http://www.sagpya.mecon.gov.ar. Accessed 15 December 2006 (in Spanish)

SAGPyA (2008) Más de 260 millones de dólares en exportaciones de biodiesel durante 2007. Press communication

Searchinger T, Heimlich R, Houghton RA, Dong F, Elobeid A, Fabiosa J, Tokgoz S, Hayes D, Yu TH (2008) Use of U.S. croplands for biofuels increases greenhouse gases through emissions from land use change. Science 319(5867):1238-1240

SERP (Secretaría de Energía de la República Argentina) (2006) Cálculo del factor de emisiones de $\mathrm{CO}_{2}$ de la red argentina de energía eléctrica. Available at: http://energia3.mecon.gov.ar. Accessed 4 October 2007

Sheehan J, Duffield J, Shapouri H, Graboski M, Camobrero V (1998) An overview of biodiesel and petroleum diesel life-cycles. National Renewable Energy Laboratory, US Department of Energy

Smith EG, Janzen HH, Newlands NK (2007) Energy balances of biodiesel production from soybean and canola in Canada. Can J Plant Sci 87(4):793-801

VIEWLS (2005) Environmental and economic performance of biofuels, vo I, main report. VIEWLS Project, SenterNovem

Zah R, Böni H, Gauch M, Hischier R, Lehmann M, Wäger P (2007) Ökobilanzierung von Bioenergie: Ökologische Bewertung der Treibstoffnutzung. Schlussbericht, Entwurf Version 1.3.0. EMPA, Abteilung Technologie und Gesellschaft, 2007 (in German) 